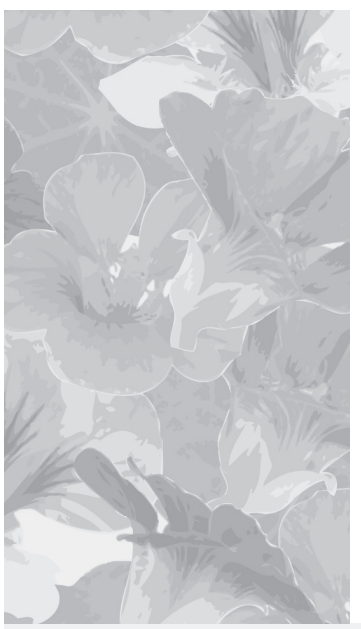

\title{
Kolagen - struktura oraz zastosowanie w kosmetologii i medycynie estetycznej
}

\section{Collagen - structure and application in cosmetology and aesthetic medicine}

Dorota Żelaszczyk ${ }^{1}$, Anna Waszkielewicz ${ }^{1}$, Henryk Marona ${ }^{1,2}$

' Pracownia Chemii Kosmetycznej Zakładu Chemii Bioorganicznej Katedry Chemii Organicznej,

Wydział Farmaceutyczny, Uniwersytet Jagielloński Collegium Medicum, Kraków

${ }^{2}$ Katedra Kosmetyki Profilaktycznej i Leczniczej, Małopolska Wyższa Szkoła im. J. Dietla, Kraków

Estetol Med Kosmetol 2012; 2(1): 14-20

DOI: http://dx.doi.org/10.14320/EMK.2012.003

\section{Streszczenie}

Kolagen jest szeroko rozpowszechnionym zewnątrzkomórkowym białkiem zwierzęcym, stanowiącym główny komponent strukturalny skóry właściwej. Ze względu na swoje właściwości biologiczne jest powszechnie stosowany w przemyśle kosmetycznym, farmaceutycznym oraz medycynie estetycznej. Celem niniejszego artykułu było przedstawienie bieżącego stanu wiedzy na temat struktury oraz zastosowania kolagenu dla celów kosmetycznych oraz estetycznych. Materiat i metody: Przeszukanie wybranych baz danych z ograniczeniem wyników poszukiwań do ostatniej dekady. Wyniki: Opisano strukturę białka oraz wyszczególniono, jakie typy kolagenu budują tkankę skórną. Przedstawiono charakterystykę dwóch kategorii preparatów kolagenowych stosowanych dla celów kosmetycznych lub estetycznych: wypełniaczy tkankowych oraz nutriceutyków. Wnioski: Potencjat terapeutyczny, jaki kryje się w kolagenie, wykorzystywany jest w medycynie estetycznej od niemal 30 lat w mało inwazyjnych zabiegach z zastosowaniem wypełniaczy tkankowych. Stosowane produkty kolagenowe różnią się pochodzeniem białka, rodzajem jego modyfikacji, wskazaniami oraz długością trwania efektu. Najnowsze badania wskazują, że warto zwrócić uwagę na kolagen również w aspekcie suplementowania diety, które może wpływać korzystnie na opóźnienie efektów chronologicznego starzenia się skóry.

Stowa kluczowe: kolagen, wypetniacze tkankowe, nutriceutyki

\begin{abstract}
Collagen is a common extracellular animal protein constituting a major structural component of the dermis. Owing to its biological properties, it is widely used in cosmetic and pharmaceutical industries as well as in aesthetic medicine. The aim of the present review was to present the current state of knowledge about the structure and application of collagen for cosmetic and aesthetic purposes. Material and methods: Literature search of selected databases with results limited to the last decade. Results: The structure of collagen and the types contributing to the skin tissue are described. The characteristics of two main categories of collagen products: tissue fillers as well as the new category of nutriceutics are discussed. Conclusions: The therapeutic potential of collagen has been exploited in aesthetic medicine for almost 30 years in minimally invasive surgery using tissue fillers. The collagen products vary in sources of the protein and types of modification, indications for use and duration of the effect. Recent studies indicate that dietary supplements containing collagen hydrolysates may be beneficial in delaying the effects of chronological skin aging.
\end{abstract}

Keywords: collagen, soft tissue fillers, nutriceutics

Copyright @ 2012 the Authors (text) and Radostaw Śpiewak (layout \& journal compilation). All rights reserved.

Kolagen jest naturalnym polimerem o bardzo konserwatywnej budowie. Jest dominującym elementem macierzy zewnątrzkomórkowej większości tkanek łącznych u ssaków, stanowi około jednej trzeciej białek w organizmie i pełni głównie funkcje strukturalne. Parametry krytyczne, takie jak: gęstość, upakowanie i orientacja wpływają na wyraźnie różne właściwości tkanek: kości, chrząstek, ścięgien czy skóry, w których kolagen stanowi najbardziej istotne białko strukturalne [1]. Ze względu na swoje właściwości biologiczne, nietoksyczność, biozgodność ze wszystkimi organizmami żywymi oraz rozpowszechnienie, kolagen jest powszechnie stosowany jako biomateriał w farmacji oraz medycynie. Preparaty kolagenowe stosowane dla celów kosmetycznych lub estetycznych można podzielić na trzy podstawowe kategorie:

1. wypełniacze tkankowe stanowiące największą grupę preparatów kolagenowych, są stosowane w postaci iniekcji, zaliczane przez amerykańską administrację żywności i leków (FDA) do kategorii wyrobów medycznych (ang. medical devices),

2. nutriceutyki - suplementy diety zawierające kolagen oraz jego hydrolizaty stosowane doustnie,

3 . preparaty do aplikowania na skórę w postaci kremów, żeli czy też masek.

Ze względu na wysoką masę cząsteczkową kolagen nie ma możliwości penetrowania przez naskórek, działa na powierzchni skóry ograniczając transepidermalną utratę wody poprzez tworzenie hydrofilowego filmu, czy też wywierając działanie ochronne poprzez częściowe niwelowanie działania anionowych środków powierzchniowo czynnych. Na ten temat praktycznie nie ma nowych publikacji naukowych i nie są one przedmiotem niniejszego opracowania. 


\section{Cel}

Celem niniejszej pracy było przedstawienie aktualnego stanu wiedzy na temat struktury kolagenu, jego pochodzenia, modyfikacji oraz zastosowania w medycynie estetycznej oraz nutriceutykach.

\section{Materiat i metody}

W pracy dokonano przeglądu największych biomedycznych baz bibliograficznych Scopus i Medline. Zastosowano następujące słowa kluczowe: collagen [chemical substance] AND (cosmetic OR aesthetic), zawężając lata publikacji wyszukanych artykułów do ostatniej dekady. Wyniki uzupełniono również używając wyszukiwarek Google Scholar oraz Google Books.

\section{Wyniki}

Struktura kolagenu. Kolagen to strukturalne białko zewnątrzkomórkowe, stanowiące niemal 1/3 całkowitej masy białka w organizmie ludzkim. Będąc najważniejszym składnikiem macierzy zewnątrzkomórkowej jest dla skóry białkiem kluczowym, odpowiadającym za jej elastyczność i wytrzymałość. Nadrodzina kolagenu u kręgowców liczy 28 typów, numerowanych cyframi rzymskimi [2], zbudowanych z conajmniej 46 różnych łańcuchów polipeptydowych [1]. Wspólną cechą strukturalną kolagenów jest obecność potrójnej spirali (superhelisy), której zawartość w poszczególnych typach waha się od 96\% w kolagenie I do mniej niż 10\% w kolagenie XII. Prawoskrętna potrójna helisa tropokolagenu składa się z trzech lewoskrętnych łańcuchów polipeptydowych, nazywanych łańcuchami $\alpha$. Potrójna helisa ma długość $300 \mathrm{~nm}$ i średnicę 1,5 nm. Na obu końcach struktury znajdują się telopeptydy odpowiedzialne za immunogenność białka [3]. Występujący w produktach medycznych tropokolagen pozbawiony telopeptydów nazywany jest atelokolagenem. Długość łańcuchów $\alpha$ zawiera się między 662 (ludzki $\alpha 1(\mathrm{X}))$ aż do 3152 (ludzki a 3(VI)) aminokwasów [4]. Łańcuchy w potrójnej helisie mogą być identyczne i tworzyć homotrimery (np. kolagen III) albo różnić się i tworzyć heterotrimery (np. kolagen VI). Wszystkie białka z rodziny kolagenów zbudowane są wyłącznie z aminokwasów endogennych (potrójna helisa jest stabilizowana dzięki obecności glicyny, dużej zawartości proliny oraz hydroksyproliny tworzących wiązania wodorowe oraz dzięki oddziaływaniom elektrostatycznym między lizyną i kwasem asparginowym $[5,6])$. Łańcuchy $\alpha$ składają się głównie z powtórzeń sekwencji Gly-X-Y, w których X to zwykle prolina a Y to 4-hydroksyprolina. Obecność oraz znaczenie reszt 3-hydroksyproliny w tworzeniu struktur wyższego rzędu potwierdzono w kolagenie I, II, III oraz V i XI [7]. Elastyczność potrójnej helisy zapewniają zaburzenia w powtórzeniach Gly-X-Y oraz w budowie łańcuchów $\alpha$. Kolagen przybiera zróżnico- wane struktury wyższego rzędu - od ściśle zorganizowanych włókien (kolagen fibrylarny), poprzez układy sieciowe, kolageny z przerwaną strukturą superhelisy zasocjowane z fibrylami (FACITs), kolageny z przerwaną strukturą superhelisy związane z błoną komórkową (MACITs), czy też struktury z wielokrotnie przerwaną strukturą superhelisy tzw. multiplexin.

Dominującą formą kolagenu (85-90\%) w skórze człowieka jest kolagen I, który stanowi włóknistą podporę skóry, a także kolagen III (do 15\%), który oplata włókna zbudowane $z$ kolagenu I i odpowiada za prawidłowe ich ułożenie, a także za sprężystość skóry [8,9]. Kolagen typu III przeważa w skórze płodu i noworodka oraz w tkance blizn. W skórze człowieka wykryto również śladowe ilości kolagenów V, VI, VII, VIII, XII, XIII, XIV oraz XVI (tabela 1). Kolagen syntetyzowany jest w fibroblastach, a w skład aminokwasów budujących go wchodzą wyłącznie aminokwasy endogenne. W organizmie kolagen ulega biodegradacji w złożonym mechanizmie enzymatycznym, w który zaangażowane są metaloproteinazy macierzy zewnątrzkomórkowej (ang. matrix metaloproteinase, MMP), głównie MMP1, MMP-2 oraz MMP-9, przecinające wiązania peptydowe między glicyną a leucyną bądź izoleucyną [10,11]. Wskutek tego cząsteczki kolagenu rozpadają się do wielkocząsteczkowych produktów, które następnie cięte są przez nieswoiste enzymy proteolityczne na peptydy i aminokwasy. Istnieje również możliwość degradacji kolagenu wewnątrzkomórkowo, jeśli cząsteczka białka zostanie wchłonięta przez komórkę na drodze fagocytozy.

Tabela 1. Typy kolagenów występujących w skórze [1]

\begin{tabular}{|c|c|c|c|}
\hline Тур & Struktura & Sklad & $\begin{array}{l}\text { Rozmieszczenie/ } \\
\text { występowanie }\end{array}$ \\
\hline I & Włókna & $\alpha 1[\mathrm{I}] 2 \alpha 2[\mathrm{I}]$ & $\begin{array}{l}\text { Skóra, kości, } \\
\text { ścięgna, więzadła }\end{array}$ \\
\hline III & Włókna & $\alpha 1[\mathrm{III}] 3$ & $\begin{array}{l}\text { Skóra, naczynia } \\
\text { krwionośne, jelita }\end{array}$ \\
\hline $\mathrm{V}$ & Włókna & $\begin{array}{l}\alpha 1(\mathrm{~V}) 3, \\
\alpha 1(\mathrm{~V}) 2 \alpha 2(\mathrm{~V}), \\
\alpha 1(\mathrm{~V}) \alpha 2(\mathrm{~V}) \alpha 3(\mathrm{~V})\end{array}$ & $\begin{array}{l}\text { Kości, skóra, } \\
\text { rogówka, łożysko }\end{array}$ \\
\hline VI & Układ sieciowy & $\begin{array}{l}\alpha 1(\mathrm{VI}) \alpha 2(\mathrm{VI}) \alpha 3(\mathrm{VI}) \\
\alpha 1(\mathrm{VI}) \alpha 2(\mathrm{VI}) \alpha 4(\mathrm{VI})\end{array}$ & $\begin{array}{l}\text { Kości, chrząstki, } \\
\text { rogówka, skóra }\end{array}$ \\
\hline VII & $\begin{array}{l}\text { Włókna } \\
\text { zakotwiczone }\end{array}$ & $\alpha 1(\mathrm{VII}) 2 \alpha 2(\mathrm{VII})$ & $\begin{array}{l}\text { Skóra, pęcherz } \\
\text { moczowy }\end{array}$ \\
\hline VIII & $\begin{array}{l}\text { Układy } \\
\text { sieciowy }\end{array}$ & $\begin{array}{l}\alpha 1[\mathrm{VIII}]_{3}, \\
\alpha 2[\mathrm{VIII}]_{3}, \\
\alpha 1[\mathrm{VIII}]_{2} \alpha 2[\mathrm{VIII}]\end{array}$ & $\begin{array}{l}\text { Skóra, mózg, serce, } \\
\text { nerki }\end{array}$ \\
\hline XII & FACIT & $\alpha 1[\mathrm{XII}]_{3}$ & Skóra, ścięgna \\
\hline XIII & MACIT & - & $\begin{array}{l}\text { Komórki } \\
\text { śródbłonka, skóra, } \\
\text { oczy, serce }\end{array}$ \\
\hline XIV & FACIT & $\alpha 1[\mathrm{XIV}]_{3}$ & $\begin{array}{l}\text { Kości, skóra, } \\
\text { ścięgna }\end{array}$ \\
\hline XVI & FACIT & - & Skóra, nerki \\
\hline
\end{tabular}


Z wiekiem w skórze spada tempo syntezy kolagenu, zmniejszeniu ulega aktywność enzymów biorących udział w modyfikacjach posttranslacyjnych, zmniejsza się rozpuszczalność kolagenu, a włókna kolagenu ulegają ścieńczeniu [12]. Zwiększa się udział ilościowy kolagenu III. W skórze starzejącej się, poddawanej działaniu promieniowania UV obserwuje się pofragmentowanie włókien kolagenowych na skutek zwiększonej aktywności MMP, których aktywność zwiększa się pod wpływem promieniowania UV, obserwuje się również wzrost stężenia tych enzymów z wiekiem [13]. Oprócz zwiększonej fragmentacji i degradacji kolagenu, wykazano zaburzenia czynności fibroblastów starzejącej się skóry, czego skutkiem jest spowolnienie syntezy i wymiany kolagenu. Jest bardzo prawdopodobne, że zmniejszona biosynteza przy zwiększonej degradacji kolagenu w podeszłym wieku może być przyczyną zaniku skóry (ang. dermal atrophy) i słabego gojenia się ran u osób starszych. W procesie starzenia się skóry, oprócz spadku elastyczności związanej ze zmniejszeniem ilości włókien kolagenu oraz elastyny, obserwuje się dodatkowo zmniejszenie ilości i redystrybucję podskórnej tkanki tłuszczowej oraz osłabienie mięśni twarzy, czego skutkiem jest pojawienie się zmarszczek grawitacyjnych oraz zauważalne zmiany w owalu twarzy. Jedną ze strategii przeciwdziałania tym zjawiskom jest próba uzupełnienia zasobów kolagenu w skórze oraz niwelowania efektów jego ubytku.

Kolagen w wypełniaczach. Dobrze rozwiniętą dziedziną małoinwazyjnej medycyny estetycznej jest stosowanie wypełniaczy mających na celu wyrównanie powierzchni skóry w miejscu zmarszczek lub zanikowych blizn oraz modelowanie owalu twarzy czy ust. Są to substancje, które wstrzyknięte śródskórnie mają zdolność czasowego lub trwałego wypełnienia ubytków tkanek miękkich - zarówno wrodzonych, jak i nabytych. Rozróżnia się wypełniacze

Tabela 2. Charakterystyka najważniejszych wypełniaczy

\begin{tabular}{|c|c|c|c|c|c|c|}
\hline & Sklad & Wskazania i miejsce podania & $\begin{array}{c}\text { Próby } \\
\text { uczuleniowe }\end{array}$ & Trwalość efektu & Producent & Lit. \\
\hline \multicolumn{7}{|c|}{ Wypełniacze ksenogeniczne } \\
\hline Zyderm $\circledast$ I i II & $\begin{array}{l}\text { Oczyszczony atelokolagen } \\
\text { pochodzenia bydlęcego, końcowe } \\
\text { stężenie białka } 65 \mathrm{mg} / \mathrm{ml} \text { (Zyderm } \\
\text { II) i } 35 \mathrm{mg} / \mathrm{ml} \text { (Zyderm I), preparat } \\
\text { zawiera lidokainę }\end{array}$ & $\begin{array}{l}\text { Korekcja powierzchownych zmarszczek } \\
\text { (poziome bruzdy na czole, zmarszczki } \\
\text { gładzizny czoła, kurze łapki, bruzdy palacza), } \\
\text { a także powierzchownych blizn }\end{array}$ & Tak & 3-4 miesięcy & $\begin{array}{l}\text { Inamed aesthetics, } \\
\text { Santa Barbara, CA, } \\
\text { USA }\end{array}$ & [15] \\
\hline Zyplast ${ }^{\circledR}$ & $\begin{array}{l}\text { Oczyszczony atelokolagen } \\
\text { pochodzenia bydlęcego usieciowany } \\
\text { glutaraldehydem, stęż. białka } 35 \\
\mathrm{mg} / \mathrm{ml}\end{array}$ & $\begin{array}{l}\text { Korekcja "głębszych" zmarszczek takich jak } \\
\text { fałdów nosowo-wargowych, głębokich blizn } \\
\text { potrądzikowych, korekta konturów ust }\end{array}$ & Tak & 3-5 miesięcy & $\begin{array}{l}\text { Inamed aesthetics, } \\
\text { Santa Barbara, CA, } \\
\text { USA }\end{array}$ & [15] \\
\hline Evolence $(\mathbb{R}$ & $\begin{array}{l}\text { Atelokolagen pochodzenia } \\
\text { wieprzowego usieciowany D-rybozą, } \\
\text { stęż̇. } 35 \mathrm{mg} / \mathrm{ml}\end{array}$ & $\begin{array}{l}\text { Korekcja umiarkowanych oraz głębokich } \\
\text { zmarszczek, fałdów nosowo-wargowych, fałdu } \\
\text { podoczodołowego, modelowanie konturów } \\
\text { oraz kształtu ust, korekta zapadniętych } \\
\text { policzków }\end{array}$ & Nie & Do 12 miesięcy & $\begin{array}{l}\text { Ortho-McNeil } \\
\text { Pharmaceutical, Inc., } \\
\text { NY, USA }\end{array}$ & {$[16,17]$} \\
\hline Resoplast $(\mathbb{2}$ & $\begin{array}{l}\text { Oczyszczony kolagen pochodzenia } \\
\text { bydlęcego } 35 \text { oraz } 65 \mathrm{mg} / \mathrm{ml}\end{array}$ & $\begin{array}{l}\text { Korekcja powierzchownych zmarszczek, blizn } \\
\text { potrądzikowych, blizn zanikowych }\end{array}$ & Tak & $3-6$ & $\begin{array}{l}\text { Rofil Medical } \\
\text { International N.V., } \\
\text { Breda, Holandia }\end{array}$ & [18] \\
\hline Artefill@ & $\begin{array}{l}\text { Mikrosfery polimetakrylanu metylu } \\
(20 \% \mathrm{v} / \mathrm{v}) \text { o średnicy } 30-40 \mu \mathrm{m} \\
\text { zawieszone w } 3,5 \% \text { roztworze } \\
\text { atelokolagenu wołowego }(80 \% \mathrm{v} / \mathrm{v}) \text {. } \\
\text { Zawiera lidokainę }\end{array}$ & $\begin{array}{l}\text { Korekcja bruzd, blizn potrądzikowych, fałdów } \\
\text { nosowo-wargowych oraz rynienki podnosowej, } \\
\text { podnoszenie kącików ust }\end{array}$ & Tak & $\begin{array}{l}\text { Trwały } \\
\text { (niewchłanialny) }\end{array}$ & $\begin{array}{l}\text { Artes Medical Inc, } \\
\text { San Diego, CA, USA }\end{array}$ & {$[19,20]$} \\
\hline \multicolumn{7}{|c|}{ Wypełniacze allogeniczne } \\
\hline $\begin{array}{l}\operatorname{Cosmoderm} \circledast \\
\text { I i II }\end{array}$ & $\begin{array}{l}\text { Oczyszczony ludzki kolagen typu } \\
\text { I i III uzyskany drogą bioinżynierii } \\
\text { (inżynierii genetycznej) w stężeniu } \\
3,5 \% \text { w/w (Cosmoderm } ® \text { I) lub 6,5\% } \\
\text { Cosmoderm® II. Zawiera lidokainę }\end{array}$ & Korekcja zmarszczek powierzchownych & $\mathrm{Nie}$ & 3-4 miesiące & $\begin{array}{l}\text { Inamed Corporation, } \\
\text { Santa Barbara, CA, } \\
\text { USA }\end{array}$ & [21] \\
\hline Cosmoplast $₫$ & $\begin{array}{l}\text { Oczyszczony ludzki kolagen typu } \\
\text { I i III uzyskany drogą bioinżynierii } \\
\text { (inżynierii genetycznej) w stężzeniu } \\
35 \mathrm{mg} / \mathrm{ml} \text {, usieciowany aldehydem } \\
\text { glutarowym. Zawiera lidokainę }\end{array}$ & $\begin{array}{l}\text { Korekcja "głębszych" zmarszczek, fałdów } \\
\text { nosowo-wargowych, konturów ust, grzbietu } \\
\text { nosa, podnoszenie kącików ust }\end{array}$ & $\mathrm{Nie}$ & 3-7 miesięcy & $\begin{array}{l}\text { Inamed Corporation, } \\
\text { Santa Barbara, CA, } \\
\text { USA }\end{array}$ & {$[22,23]$} \\
\hline Cymera® & $\begin{array}{l}\text { Zawiera kolagen, lamininę, elastynę } \\
\text { oraz proteoglikany pozyskane ze } \\
\text { skóry zmarlych dawców, } \\
330 \mathrm{mg} / 5 \mathrm{~cm}^{3}\end{array}$ & $\begin{array}{l}\text { Korekcja blizn potrądzikowych, fałdów } \\
\text { nosowo-wargowych, linii marionetki, } \\
\text { bruzd palaczy, opadniętych kącików ust, } \\
\text { modelowanie konturów ust }\end{array}$ & $\mathrm{Nie}$ & 3-6 miesięcy (?) & $\begin{array}{l}\text { LifeCell Corp., } \\
\text { Branchburg, N.J., } \\
\text { USA }\end{array}$ & [24] \\
\hline Fascian $\sqrt{(2}$ & $\begin{array}{l}\text { Kolagen pozyskiwany z powięzi od } \\
\text { zmarłych dawców } 40 \mathrm{mg} / \mathrm{ml}\end{array}$ & Korekcja głębokich zmarszczek oraz blizn & $\mathrm{Nie}$ & 3-6 miesięcy & $\begin{array}{l}\text { Fascia Biomaterials, } \\
\text { Beverly Hills, CA, } \\
\text { USA }\end{array}$ & [25] \\
\hline \multicolumn{7}{|c|}{ Wypelniacze autologiczne } \\
\hline Isolagen ( & $\begin{array}{l}\text { Wyhodowane autologiczne żywe } \\
\text { fibroblasty wraz z macierzą } \\
\text { zewnątrzkomórkową }\end{array}$ & $\begin{array}{l}\text { Korekcja zmarszczek powierzchownych } \\
\text { oraz umiarkowanych, poziomych bruzd } \\
\text { czoła, zmarszczek gładzizny, bruzd, blizn, } \\
\text { modelowanie konturów ust }\end{array}$ & Tak & $\begin{array}{l}\text { Do } 18 \text { miesięcy, } \\
\text { opóźniony } \\
\text { początek działania }\end{array}$ & $\begin{array}{l}\text { Fibrocell } \\
\text { Technologies, Inc. } \\
\text { (uprzednio Isolagen } \\
\text { Technologies, Inc.), } \\
\text { Exton, PA, USA }\end{array}$ & [26] \\
\hline
\end{tabular}


pochodzenia syntetycznego oraz naturalnego, które z kolei można podzielić na ksenogeniczne (z tkanek zwierzęcych), allogeniczne (z tkanek innych ludzi, najczęściej ze skóry właściwej i powięzi) oraz autogeniczne (z tkanek własnych). Pod względem szybkości wchłaniania preparaty kolagenu dzieli się na trwałe - niewchłanialne oraz czasowe, czyli wchłanialne.

Wypełniacze kolagenowe (tabela 2) stanowią najstarszą grupę wypełniaczy tkankowych, stosuje się je od początków lat 80-tych ubiegłego wieku, i od tego czasu są nieustannie przedmiotem badań i różnego typu modyfikacji w poszukiwaniu idealnego wypełniacza. Idealny wypełniacz tkankowy powinien spełniać szereg wymagań: dawać powtarzalny, długotrwały, chociaż nie permanentny wynik, powinien być tani, prosty w produkcji oraz stosowaniu, powinien mieć naturalną konsystencję, dobrą wytrzymałość mechaniczną, być biodegradowalny, nietoksyczny, niekancerogenny, nieteratogenny, nieimmunogenny, nie wywoływać stanów zapalnych ani ulegać przemieszczeniom, być uniwersalnym w zastosowaniu, w razie potrzeby dawać się łatwo usunąć [14]. Żaden z aktualnie stosowanych wypełniaczy nie spełnia wszystkich wymienionych wymagań. Uzgodnienia chirurgów plastycznych i dermatologów (Professional Educational Meeting Panel, Berlin 2005) doprowadziły do zawężenia tych wymagań do dwóch podstawowych: idealny wypełniacz powinien być biodegradowalny, a jego efekt powinien utrzymywać się przez co najmniej 12 miesięcy, jednak nie dłużej niż przez 2 lata. Z wyjątkiem preparatu Artefill@, który zawiera kolagen bydlęcy w połączeniu z polimetakrylanem metylu, wypełniacze kolagenowe są w pełni biodegradowalne ale nie spełniają podanego kryterium trwałości efektu. Warto jednak podkreślić, że są stosunkowo łatwe w produkcji, stosunkowo tanie, nietoksyczne, niekancerogenne oraz nieteratogenne, a ich zastosowanie daje powtarzalne wyniki, dzięki czemu są one bardzo popularne. Wadą preparatów kolagenowych są występujące działania niepożądane, które pojawiają się w różnym natężeniu, w zależności od zastosowanego preparatu (tabela 3 ). Należy również pamiętać o możliwości przeniesienia wirusów i prionów w przypadku ksenogenicznych i allogenicznych preparatów kolagenowych.

Analiza dostępnych preparatów kolagenowych pozwala prześledzić modyfikacje, jakim podlegały one w celu dostosowania do stawianych wymagań. Jako pierwsze wprowadzono na rynek wypełniacze na bazie kolagenu bydlęcego Zyderm ${ }^{\circledR}$ I oraz Zyderm ${ }^{\circledR}$ II, które różnią się zawartością białka zwierzęcego. Zawierają głównie kolagen typu I (około 96\%) z domieszką typu III (około 4\%), uzyskany ze skóry cieląt metodą ekstrakcji enzymatycznej. Zastosowanie pepsyny służyło pozbyciu się telopeptydów, które w głównej mierze są odpowiedzialne za immunogenność białka. Prepa- ratem o zbliżonym do Zydermu ${ }^{\circledR}$ składzie oraz właściwościach był Resoplast ${ }^{\circledR}$. Zyplast ${ }^{\circledR}$ zawierał takie samo stężenie atelokolagenu jak Zyderm ${ }^{\circledR}$ I, cząsteczki białka zostały jednak poddane procesowi usieciowania reszt lizynowych aldehydem glutarowym (zawartość 0,0075\%). Miało to na celu wzmocnienie włókien kolagenowych oraz wydłużenie czasu utrzymywania się efektu. Zyderm ${ }^{\circledR}$ oraz Zyplast ${ }^{\circledR}$ stosowano w korekcji płytkich i umiarkowanych zmarszczek. Oprócz stosunkowo krótkiego czasu trwania efektu wypełnienia, wadą stosowania kolagenu bydlęcego są występujące reakcje alergiczne typu opóźnionego odnotowywane u 1,5-3,0\% populacji, w wyniku czego konieczne jest dwukrotne wykonanie testu skórnego na alergię przed zabiegiem [28].

Tabela 3. Działania niepożądane po zastosowaniu wypetniaczy kolagenowych [27]

\begin{tabular}{l} 
Reakcje wczesne $^{\mathbf{a}}$ \\
\hline Miejsce wstrzyknięcia: rumień, obrzęk, ból, zasinienie, świąd \\
\hline $\begin{array}{l}\text { Infekcje: zaczerwienienie, obrzęk, ból/tkliwość, powstawanie } \\
\text { grudek, guzków }\end{array}$ \\
\hline $\begin{array}{l}\text { Nadwrażliwość: zaczerwienienie, obrzęk, ból/tkliwość, twarde } \\
\text { guzki }\end{array}$ \\
\hline Przebarwienia: zaczerwienienie, zblednięcie, hiperpigmentacja \\
\hline Reakcje opóźnione \\
\hline $\begin{array}{l}\text { Infekcje (atypowe, najczęściej Mycobacterium): zaczerwienienie, } \\
\text { obrzęk, ból/tkliwość, guzki, objawy ogólne }\end{array}$ \\
\hline Tworzenie ziarniniaków: duże, szpecące guzki zapalne \\
\hline Nadwrażliwość: ropnie jałowe, trwałe przebarwienia, blizny \\
\hline
\end{tabular}

${ }^{a}$ pojawiają się do kilku dni po zabiegu,

${ }^{b}$ pojawiają się od kilku tygodni do kilku lat po zabiegu

Poszukując preparatów kolagenowych o zmniejszonej immunogenności wprowadzono kolagen otrzymywany drogą bioinżynierii z hodowli ludzkich fibroblastów (preparaty Cosmoderm ${ }^{\circledR}$ oraz Cosmoplast $\AA$ ). Cosmo$\operatorname{derm}{ }^{\circledR} 1$ oraz 2 , a także Cosmoplast ${ }^{\circledR}$ zawierają przede wszystkim kolagen typu I (93\%) oraz typu III (7\%). Cosmoplast ${ }^{\circledR}$ zawiera kolagen usieciowany aldehydem glutarowym, co wydłuża efekt jego działania. Ze względu na biozgodność białka, przed zabiegiem nie są wymagane testy na alergię. Również ryzyko wystąpienia i nasilenie innych działań niepożądanych jest mniejsze niż po podaniu białka bydlęcego. Wypełniacze allogeniczne pozyskiwane są z tkanek osób zmarłych. Cymera ${ }^{\circledR}$ zawiera acelularną (bezkomórkową) macierz skóry zmarłych dawców. W procesie liofilizacji eliminuje się komponenty komórkowe, pozostawiając kolagen, lamininę, elastynę oraz proteoglikany. Fascian ${ }^{\circledR}$ zawiera kolagen otrzymany z powięzi zmarłych dawców. Tkanki zmarłych dawców są poddawane badaniom na obecność czynników zakaźnych i teratogennych przez Amerykańskie Towarzystwo Banków Tkanek (American Association of Tissue Banks). Czas utrzymywania 
się efektu w przypadku obu wypełniaczy jest dłuższy w porównaniu do preparatów zawierających kolagen bydlęcy, nie jest konieczne wykonywanie testów na alergię, również objawy niepożądane występują rzadziej.

Do najnowszych form terapii kolagenowych zaliczamy Isolagen $\AA$. Nie jest to wypełniacz kolagenowy lecz zawiesina żywych kultur fibroblastów i macierzy zewnątrzkomórkowej pochodzących ze skóry pacjenta. Zdolne do namnażania oraz syntezy kolagenu fibroblasty uzyskuje się z wycinka skóry pacjenta, hoduje in vitro przez około 6 tygodni, a następnie podaje w formie iniekcji. Działanie korygujące zmarszczki po wstrzyknięciu fibroblastów związane jest z syntezą nowych składników macierzy zewnątrzkomórkowej i stymulacją przebudowy istniejących komponentów tkanki, a co za tym idzie efekt wizualny pojawia się z opóźnieniem [29]. Wadą jest również wysoki w porównaniu z innymi wypełniaczami tkankowymi koszt terapii. Ze względu na ryzyko wystąpienia reakcji nadwrażliwości zaleca się wykonanie jednorazowego testu na alergię.

Spośród nowych wypełniaczy ksenogenicznych, najmniej alergizującym i niewymagającym testów przed zastosowaniem jest preparat Evolence $\AA$ [30], zawierający oczyszczony atelokolagen ze ścięgien wieprzowych usieciowany D-rybozą. Dzięki procesowi usieciowania za pomocą naturalnie występującego $\mathrm{w}$ organizmie ludzkim cukru uzyskano wydłużenie czasu utrzymywania się efektu, bez zwiększenia ryzyka wystąpienia działań niepożądanych. Wypełniaczem o najdłużej utrzymującym się efekcie jest Artefill@ - trzeciej generacji preparat zawierający mikrosfery polimetakrylanu metylu $(20 \% \mathrm{v} / \mathrm{v})$ zawieszone w 3,5\% roztworze atelokolagenu bydlęcego $(80 \% \mathrm{v} / \mathrm{v})$ [31]. Z racji zawartości polimetakrylanu metylu, Artefill ${ }^{\circledR}$ zaliczany jest do grona wypełniaczy tzw. trwałych (niewchłanialnych), a kolagen bydlęcy stanowi nośnik dla cząsteczek polimeru, zapewniając mu odpowiednie rozproszenie. Kolagen bydlęcy w ciągu 1-3 miesięcy ulega w organizmie ludzkim biodegradacji i zastąpieniu przez kolagen własny. Kierując się doświadczeniami z badań nad preparatami poprzedniej generacji zawierających mikrosfery o średnicy poniżej $20 \mu \mathrm{m}$ (Arteplast ${ }^{\circledR}$, Artecoll®), zoptymalizowano średnicę mikrosfer, która w preparacie Artefill® wynosi 30-50 $\mu \mathrm{m}$. Wykazano, że mikrosfery o średnicy poniżej $20 \mu \mathrm{m}$ szybciej/łatwiej ulegają fagocytozie, czego następstwem jest powstawanie komórek olbrzymich (ang. giant cells) i ziarniniaków.

Kolagen ksenogeniczny znajduje szerokie zastosowanie w medycynie, między innymi w niciach chirurgicznych, kompresach, nośnikach itp., jednak jego wadą jest immunogenność. Czynnikiem ograniczającym stosowanie kolagenów allogenicznych i autogenicznych jest cena, a w przypadku niedokładnie oczyszczonych produktów alogenicznych również ryzyko wprowadzenia do orga- nizmu pacjenta wirusów lub prionów. W związku z tym od kilku lat trwają intensywne badania nad pozyskaniem kolagenu na drodze w pełni syntetycznej [32-34].

Kolagen oraz hydrolizaty kolagenu w nutriceutykach. Do tej pory najwięcej preparatów doustnych zawierających kolagen lub jego hydrolizaty miało zastosowanie w profilaktyce schorzeń związanych ze zmianami w tkance łącznej, głównie chrzęstno-stawowej. Obecnie na rynku europejskim pojawiają się nowe suplementy diety zawierające kolagen, których głównym wskazaniem jest poprawa wyglądu skóry, a także profilaktyka, a raczej opóźnienie efektów starzenia skóry. Podczas gdy w Europie doustne preparaty na bazie hydrolizatów kolagenu ze wskazaniem estetycznym dopiero zaczęły się pojawiać, na innych rynkach (np. w Japonii) stanowią one już od kilku lat znaczącą kategorię nutriceutyków. Warto zaznaczyć, że literatura na temat wpływu zażywania suplementów diety zawierających kolagen lub jego hydrolizaty jest bardzo uboga. Pierwsze publikacje opisywały badania in vitro na liniach komórkowych i głównie opisywały wzmożoną syntezę kolagenu przez fibroblasty pod wpływem poszczególnych aminokwasów wchodzących w skład kolagenu, np. argininy, glicyny czy hydroksyproliny, a także wzrost proliferacji komórek skóry i syntezy kolagenu pod wpływem hydroksyproliny [35]. Opisywano także wzrost poziomu nawilżenia skóry jako efekt przyjmowania hydrolizatów kolagenu [36]. W badaniach na ludziach wykazano po spożyciu żelatyny znaczący, utrzymujący się ponad 4 godziny, wzrost stężenia we krwi peptydów pochodzących z trawienia kolagenu, głównie opornego na działanie peptydaz dipeptydu Pro-Hyp [37-39]. $\mathrm{W}$ badaniach in vitro wykazano stymulujący wpływ Pro-Hyp na wzrost fibroblastów pobranych ze skóry myszy [40], zwiększoną syntezę glikozoaminoglikanów [41] oraz kwasu hialuronowego przez kultury ludzkich fibroblastów [42]. Próbuje się te obserwacje powiązać z sugerowanym wpływem ochronnym na tkankę łączną oraz nawilżającym efektem na skórę przyjmowanych doustnie hydrolizatów kolagenu. Nowe badania prowadzone in vivo na zwierzętach (szczury) potwierdzają pozytywny wpływ codziennego suplementowania hydrolizatami kolagenu bydlęcego na białka macierzy zewnątrzkomórkowej. W porównaniu z grupą kontrolną wzrosła względna ilość kolagenu I oraz IV w pobranych próbkach skóry, jak również obniżyła się ilość zarówno proenzymu, jak i aktywnej formy kolagenazy typu 2, enzymu odpowiedzialnego za degradację kolagenu [43]. Wyniki te sugerują, że suplementacja hydrolizatami kolagenu może opóźnić związane z wiekiem zmiany w macierzy zewnątrzkomórkowej i stymulować procesy anaboliczne w tkance skóry. W badaniach nad starzeniem się szczurów, potwierdzono, że długotrwałe podawanie tym zwierzętom hydrolizatu kolagenu rybiego stymulowało biosyntezę kolagenu typu I oraz III i zmniejszało aktywność kolagenazy typu 1, a ponadto 
udowodniono, że produkty hydrolizy kolagenu mogą łagodzić stres oksydacyjny [44]. Wszystkie powyższe obserwacje sugerują, że stosowanie doustne hydrolizatów kolagenu może stanowić korzystną metodę spowalniającą proces chronologicznego starzenia się skóry.

\section{Wnioski}

Kolagen jest unikalnym białkiem, zapewniającym tkankom ludzkim i zwierzęcym niezwykłą wytrzymałość przy zachowaniu dużej elastyczności. Potencjał terapeutyczny kolagenu wykorzystuje się obecnie głównie $\mathrm{w}$ medycynie estetycznej $\mathrm{w}$ zabiegach modelowania struktury skóry. W ostatnich 30 latach nastąpiła znaczna ewolucja w produkcji preparatów zawierających kolagen - od preparatów zwierzęcych (bydlęcych) poprzez preparaty pochodzące od zmarłych dawców, kolageny uzyskiwane $\mathrm{z}$ hodowli ludzkich fibroblastów, aż po preparat zawierający autologiczny kolagen. Zmniejszono ryzyko reakcji alergicznych, zmarginalizowano zagrożenie zakażenia wirusami i prionami, wydłużono okres utrzymywania się efektu wypełniaczy. Nowsze badania pokazują ponadto, że warto zwrócić uwagę na to białko również w aspekcie suplementowania diety. Szereg badań prowadzonych in vitro, a także in vivo na zwierzętach wskazuje na korzystne działanie hydrolizatów tego białka na produkcję endogennego kolagenu oraz zmniejszenie aktywności enzymów odpowiadających za jego degradację, co może korzystnie wpływać na opóźnienie efektów chronologicznego starzenia się skóry.

\section{Piśmiennictwo}

1. Schoulders MD, Raines RT: Collagen structure and stability. Annu Rev Biochem 2009;78:929-58.

2. Ricard-Blum S: The collagen family. Cold Spring Harb Perspect Biol 2011 1;3(1):a004978.

3. Lynn AK, Yannas IV, Bonfield W: Antigenicity and immunogenicity of collagen. J Biomed Mater Res B Appl Biomater 2004;71(2):343-54.

4. Gordon MK, Hahn RA: Collagens. Cell Tissue Res 2010;339(1):247-57.

5. Persikov AV, Ramshaw JA, Kirkpatrick A, Brodsky B: Electrostatic interactions involving lysine make major contributions to collagen triple-helix stability. Biochemistry 2005;44(5):1414-22.

6. Fallas JA, Gauba V, Hartgerink JD: Solution structure of an $\mathrm{ABC}$ collagen heterotrimer reveals a single-register helix stabilized by electrostatic interactions. J Biol Chem 2009;284(39): 26851-9.

7. Weiss MA, Hudson DM, Kim L, Scott M, Wu JJ, Eyre DR: Location of 3-hydroxyproline residues in collagens I, II, III, ad V/XI implies a role in fibril supramolecular assembly. J Biol Chem 2010;285(4):2580-90.

8. Chung JH, Seo JY, Choi HR, Lee MK, Youn CS, Rhie G, Cho KH, Kim KH, Park KC, Eun HC: Modulation of skin collagen metabolism in aged and photoaged human skin in vivo. J Invest Dermatol 2001;117(5):1218-24.

9. Tayebjee MH, MacFadyen RJ, Lip GYH: Extracellular matrix biology: a new frontier invlinking the pathology and therapy of hypertension? J Hypertens 2003;21(12):2211-8.

10. Abdul-Hussien H, Soekhoe RG, Weber E, von der Thüsen JH, Kleemann R, Mulder A, van Bockel JH, Hanemaaijer $\mathrm{R}$, Lindeman JH: Collagen degradation in the abdominal aneurysm: a conspiracy of matrix metalloproteinase and cysteine collagenases. Am J Pathol, 2007;170(3):809-17.

11. Quan T, Qin Z, Xia W, Shao Y, Voorhees JJ, Fisher GJ: Matrix-degrading metalloproteinases in photoaging. J Invest Dermatol Symp Proc 2009;14(1): 20-4.

12. Uitto J: Connective tissue biochemistry of the aging dermis. Clin Geriatr Med 1989; 5(1):127-47.

13. Varani J, Dame MK, Rittie L, Fligiel SE, Kang S, Fisher GJ, Voorhees JJ: Decreased collagen production in chronologically aged skin: roles of age-dependent alteration in fibroblast function and defective mechanical stimulation. Amer J Pathol 2006; 168(6):1861-8.

14. Buck DW 2nd, Alam A, Kim JYS: Injectable fillers for facial rejuvenation: a review. J Plast Reconstr Aesthet Surg 2009; 62(1): 11-8.

15. Ryssel H, Germann G, Koellensperger E: An overview of current biomaterials in aesthetic soft tissue augmentation. Eur J Plast Surg 2012;35(2):121-33.

16. Monstrey SJ, Pitaru S, Hamdi M, Van Landuyt K, Blondeel P, Shiri J, Goldlust A, Shoshani D: A twostage phase I trial of Evolence30 collagen for soft-tissue contour correction. Plast Reconstr Surg 2007;120(1):30311.

17. Sadick NS, Palmisano L: Cheek augmentation with Dermicol-P35 27G. Aesthet Surg J 2009;29(3 Suppl.): S5-8.

18. Dasiou-Plakida D: Dermofilers: collagen, hyaluronic acid, silicone, methacrylate, etc. W: Textbook of dermatologic surgery vol. 2, Piccin Nuova Libraria, S.p.A. Padova 2008: 741-52.

19. Bagal A, Dahiya R, Tsai V, Adamson PA: Clinical Experience With polymethylmethacrylate Microspheres (Artecoll) for Soft-Tissue Augmentation. Arch Facial Plast Surg 2007;9(4):275-80.

20. Lemperle G, Sadick NS, Knapp TR, Lemperle SM: ArteFill ${ }^{\circledR}$ Permanent Injectable for Soft Tissue Augmentation: II. Indications and Applications. Aest Plast Surg 2010;34(3):273-86.

21. Baumann L, Kaufman J, Saghari S: Collagen fillers. Dermatol Ther 2006;19(3):134-40.

22. Thioly-Bensoussan D: Non-hyaluronic acid fillers. Clin Dermatol 2008;26(2):160-76.

23. Bauman L: CosmoDerm/CosmoPlast (Human Bioengineered Collagen) for the aging face. Facial Plast Surg 2004:20(2):125-8.

24. Maloney BP, Murphy BA, Cole HP: Cymetra. Facial Plast Surg 2004;20(2):129-34.

25. Burres S: Fascian. Facial Plast Surg 2004;20(2):149-52.

26. Weiss RA, Weiss MA, Beasley KM, Munavalli G: Autologous Cultured Fibroblast Injection for Facial Contour Deformities: A Prospective, Placebo-Controlled, Phase III Clinical Trial. Dermatol Surg 2007;33(3):263-8.

27. Sadick N., Khan M.H. Rao B.K. Skin fillers. W: Cosmetic dermatology: products and procedures, Blackwell Publishing Ltd, Oxford 2009.

28. Newman J: Review of soft tissue augmentation in the face. Clin Cosmet Invest Dermatol 2009;2:141-50. 
29. Aust MC, Fernandes D, Kolokythas P, Kaplan HM, Vogt PM: Percutaneous collagen induction therapy: an alternative treatment for scars, wrinkles, and skin laxity. Plast Reconstr Surg 2008;121(4):1421-9.

30. Monstrey SJ, Pitaru S, Hamdi M, Van Landuyt K, Blondeel P, Shiri J, Goldlust A, Shoshani D: A twostage phase I trial of Evolence30 collagen for soft-tissue contour correction. Plast Reconstr Surg 2007;120(1):30311.

31. Lemperle G, Sadick NS, Knapp TR, Lemperle SM: ArteFill ${ }^{\circledR}$ Permanent Injectable for Soft Tissue Augmentation: I. Mechanism of Action and Injection Techniques. Aest Plast Surg 2010;34(3):262-73.

32. Cejas M, Kinney WA, Chen C, Leo GC, Tounge BA, Vinter JG, Joshi PP, Maryanoff BE: Collagen-related peptides: self-assembly of short, single strands into a functional biomaterial of micrometer scale. J Am Chem Soc 2007;129(8):2202-3.

33. Cejas MA, Kinney WA, Chen C, Vinter JG, Almond HRJ, Balss KM, Maryanoff CA, Schmidt U, Breslav M, Mahan A, Lacy E, Maryanoff BE: Thrombogenic collagen-mimetic peptides: self-assembly of triple helixbased fibrils driven by hydrophobic interactions. Proc Natl Acad Sci USA 2008; 105(25):8513-8.

34. Rele S, Song Y, Apkarian RP, Qu Z, Conticello VP, Chaikof EL: D-Periodic collagenmimetic microfibers. J Am Chem Soc 2007;129(47):14780-7.

35. Noguchi A, Djerassi D: Amino acids and peptides: building blocks for skin protein. W: Nutritional Cosmetics: Beauty from within. William Andrews, Oxford, 2009: 287-310.

36. Zague V: A new view concerning the effects of collagen hydrolysate intake on skin properties. Arch Dermatol Res 2008;300(9):479-83.

37. Iwai $\mathrm{K}$, Hasegawa $\mathrm{T}$, Taguchi $\mathrm{Y}$, Morimatsu $\mathrm{F}$, Sato $\mathrm{K}$, Nakamura Y, Higahsi A, Kido Y, Nakabo Y, Otsuki K: Identification of food-derived collagen peptides in human blood after oral administration of gelatin hydrolisate. J Agric Food Chem 2005;53(16):6531-6.

38. Ichikawa S, Morifuji M, Ohara M, Matsumoto H, Takeuchi Y, Sato K: Hydroxyproline containing dipeptides and tripeptides quantified at high concentrationin human blood after oral administration of gelatin hydrolisate. Int J Food Sci Nutr 2010;61(1):52-60.

39. Sato K, Shigemura Y: Effect of marine collagen peptides on skin conditions W: Marine Cosmeceuticals: Trends and Prospects, CRC Press, Taylor \& Francis Group, LCC, Boca Raton, 2011:125-132.
40. Shigemura Y, Iwai K, Morimatsu F, Iwamoto T, Mori T, Oda C, Taira T, Park EY, Nakamura Y, Sato K: Effect of prolyl-hydroxyproline (Pro-Hyp), a food-derived collagen peptide in human blood on growth of fibroblasts from mouse skin. J Agric Food Chem 2009;57(2):444-9.

41. Nakatani S, Mano H, Sampei C, Shimizu J, Wada S: Chondroprotective effect of bioactive peptide prolylhydroxyproline in mouse articular cartilage in vitro and in vivo. Osteoarthritis Cartilage 2009;17(12):1620-7.

42. Ohara $\mathrm{H}$, Ichikawa $\mathrm{S}$, Matsumoto $\mathrm{H}$, Akijama $\mathrm{M}$, Fujimoto N, Kobajashi T, Tajima S: Collagen-derived dipeptide, proline-hydroxyproline, stimulates cell proliferation and hyaluronic acid production in cultured dermal human fibroblast. J Dermatol 2010;37(4):330-8.

43. Zague V, Freitas V, Costa Rosa M, Castro GA, Jaeger RG, Machado-Santelli GM: Collagen hydrolysate intake increases skin collagen expression and suppresses matrix metalloproteinase 2 activity. J Med Food 2011;14(6):61824.

44. Liang J, Pei X, Zhang Z, Wang N, Wang J, Li Y: The protective effects of long-term oral administration of marine collagen hydrolysate from chum salmon on collagen matrix homeostasis in the chronological aged skin of Sprague-Dawley male rats. J Food Sci 2010;75 (8):H230-8.

\section{Finansowanie i konflikt interesów}

Przedstawione badania i przygotowanie niniejszej publikacji zostało $\mathrm{w}$ całości sfinansowane $\mathrm{z}$ własnych środków autorów. Wszyscy autorzy deklarują niewystępowanie konfliktu interesów w odniesieniu do treści zawartych w niniejszej pracy.

\section{Adres do korespondencji}

prof. dr hab. Henryk Marona Zakład Chemii Bioorganicznej Wydział Farmaceutyczny UJ ul. Medyczna 9, 30-688 Kraków

Tel.: 126205576

E-mail: henryk.marona@uj.edu.pl

Data złożenia: 27.02.2012

Data akceptacji: 30.03.2012

Data aktualizacji: 30.11.2012 